\title{
The Translation and Spread of J.M. Coetzee's Novels in China
}

\author{
Han Ruihui ${ }^{1}$ \\ ${ }^{1}$ Humanities School, Jinan University, Zhuhai, Guangdong Province, China \\ Correspondence: Han Ruihui, Humanities School, Jinan University, Zhuhai, Guangdong Province, China. E-mail: \\ hanruihuihh@hotmail.com
}

Received: December 11, 2013 Accepted: January 20, 2014 Online Published: February 26, 2014

doi:10.5539/ass.v10n6p117

URL: http://dx.doi.org/10.5539/ass.v10n6p117

\begin{abstract}
After J.M. Coetzee was awarded Nobel Prize in Literature in 2003, his works gave rise to the interest of literature critics and publishers and both publishing amount and sales volume increased significantly. As time went by, the sales volume of his works dropped gradually. The phenomenon is an example of decline of serious literature in China. And the phenomenon is caused by the fact that the Intelligentsia and the mass are disjointed. Besides, the decline of serious literature is also a result of prosperity of popular culture.
\end{abstract}

Keywords: J.M. Coetzee, reception of readers, translation, popular culture

\section{Introduction}

J.M. Coetzee is one of the most famous writers in South Africa and obtaining 2003 Nobel Prize in Literature made him a household name.

Compared with works by other writers in South Africa, Coetzee's novels reproduced the history of South Africa in a unique way. A researcher on Coetzee, Derek said: "The author who represents the best-known and most striking example of the tension between innovative writing and political demands in contemporary South Africa is J.M. Coetzee." (Attridge, 1998) While it turned out to be another scene in the research on this Nobel Prize winning writer's works and reception of readers in China.

The research and translation of Coetzee's works in China can be divided into two stages before and after 2003 when he was awarded Nobel Prize in Literature. There were few translation works of Coetzee's work before 2003; while after 2003, Coetzee's novels appeared in large amount in relevant review articles in China and all Coetzee's novels were also translated into Chinese and published in China in a short time.

\subsection{Translation of Coetzee's Novels in Mainland China before 2003}

Shao Diansheng, editor of the Chinese magazine "World Literature" once carried out follow-up studies on Coetzee before 1987. In 1990s, the magazine "Yilin" once introduced Coetzee's novels. (Zou, 2004) Li Yongcai once put it in his translation work "African Literature in $20^{\text {th }}$ century" that: "J.M. Coetzee (born in 1940) ... his full-length novel Dusklands (1974), In the Heart of the Country (1977) and Waiting for the Barbarians (1980) broke from the realism in South African literature." $(\mathrm{Li}, 1991)$ In the third issue of Contemporary Literature in 2000, Wang Lili commented on Coetzee's novel Disgrace with a paper themed by "An Elegy to Colonialism-Criticism on Booker Prize Winning Novel Disgrace". (Wang, 2000) And in 2001, Zhang Chong and Guo Zhengfeng from English Language Departments in Nanjing University and Nanjing Normal University respectively published a review article "Costs for Cross the Border-Interpreting Coetzee's Booker Prize Winning Novel Disgrace" on Foreign Literature. (Zhang \& Guo, 2001) In this literary review, critics regarded the behavior of Lurie, protagonist of the novel as crossing the border and the main content of the novel developed around crossing the border; in 2002, the translated novel, Disgrace by Zhang Chong was published by Yilin Press, which was the only novel by Coetzee translated into Chinese at that time.

\subsection{Translation of Coetzee's Novels in Mainland China after Winning Nobel Prize}

Winning Nobel Prize in Literature enabled Coetzee to appear more clearly in people's visual field, articles introducing or criticizing Coetzee and his works in China appeared in large numbers in China in a short time because of the Nobel Prize winning. For example, Hu Lang's article "Coetzee: an Unsocial Master in Literature" was published in the 43th issue of Outlook Weekly in 2003; Tang De's review article "Coetzee, Writer from South Africa Won Nobel Prize in Literature of this year" was published in the $4^{\text {th }}$ issue of Contemporary Foreign 
Literature in 2003; Zhou Jing's article "Zhang Chong: Bitter yet Loving Disgrace in South Africa-Chinese Translator, Professor Zhang Chong Interpreting New Nobel Prize Winner in Literature, Coetzee and His Winning Work" was published in the $11^{\text {th }}$ issue of Chinese Times in 2003. Yu Fengchuan's "Coetzee: a Born Nobel Winning Writer" was published in the $4^{\text {th }}$ issue of Sino-foreign Cultural Exchange in 2003, Ren Yibing's "Building Post-colony Literature Myth-J.M. Coetzee's Novel Artistry" was published in the $4^{\text {th }}$ issue of Social Outlook in 2003 and Du Tao's "Nobel Prize Winner, J.M. Coetzee: Honor from Disgrace" was published in the $11^{\text {th }}$ issue of Teach Yourself English in 2003. So far, the publication of articles of studies on Coetzee's novels most concentrated in a period several months later after he won the prize.

Zhejiang Literature and Art Press gained the copyright from Coetzee soon after Coetzee won the prize and translated and published his five novels: Waiting for the Barbarians, Youth, Elizabeth Costello, Life \& Times of Michael K, Master of Petersburg. In 2006, Coetzee's novels, Slow Man, The Lives of Animals and Boyhood: Scenes from Provincial Life were also translated and published by Zhejiang Literature and Art Press successively.

\subsection{Research Status and Analysis on Coetzee's Novels in Mainland China}

Years afterwards, literature reviews about Coetzee sprang up in academic journals constantly, which can be divided into two aspects including introduction to Coetzee and his works and analyses on his works. As for the introduction to Coetzee's works, studies on Coetzee's novels can be divided into critics on thought content and critics on artistic concept of novels. As for critics on single novel, review articles on Coetzee's representative work Disgrace accounted for the largest number. As for novel studies on Coetzee's works in thought and content, they can be divided into studies and critics about race relations, sexual relations, clash of civilizations, cultural identity, philosophical meaning and relationship between human and history, etc.

With regard to introduction to Coetzee, there were articles such as "Winner of Nobel Prize in Literature Who Concerns Outsiders-Coetzee" by Shi Pingping, "Coetzee: a Dissocial Master in Literature" by Hu Lang, "Coetzee: a Born Nobel Winning Writer" by Yu Fengchuan, "Coetzee's Life of Dream Seeking" by Chen Zhaorong and Diaoping and "Suth African Writer Coetzee and His Representative Disgrace" by Li Yuejin, etc. These articles all have an extensive introduction to Coetzee's life experience and conditions in his novel writing and some articles also described Coetzee's characteristics of personality. As a whole, these review articles had a brief introduction to the subject contents and creative features of Coetzee's novels. Generally speaking, these brief introductory articles considered that Coetzee's novel writing reflected the history and reality of South African society, revealed the evil of colonialism and deemed Coetzee's life experience reflected the content of Coetzee's novel writing. Through these introductions, Coetzee was more clearly showed in front of Chinese readers.

In addition to articles analyzing Coetzee and his novels as a whole, many articles had special comments on a single novel of Coetzee's works. As for studies on features of thought in Coetzee's novels, they can be divided into the following categories: those themed with race relations in South Africa, studies from the perspective of post-colonialism, those themed with philosophical meaning, studies themed by the revelation of shackle of western civilization in Coetzee's novels, studies themed by relationship between human and history in Coetzee's novels and studies on religious themes in Coetzee's novel writing.

Articles of studies on Coetzee's novels from the perspective of race relations and post-colonialism are the most. For example, there is "Unordered Revelry and Circular Shame-Coetzee and his Disgrace" (Shi, 2004) by Shi Song with discussion focusing on dilemma of communication between people in different races under specific historical conditions in South Africa and an unordered state showed in this dilemma, "Historical Memory and National Allegory-on Disgrace" (Cai \& Yan, 2005) by Cai Tongqing and Yan Xiaojun discussed white people's awkward condition in post-racial segregation time and pointed out that Coetzee was suspected with West Centralism and in a sense both the west and South Africa became Coetzee's otherness; "Echo of Realism Literature Towards Clash of Civilizations Theory-Perusal of Coetzee's Novel Disgrace" (Cai, 2004) by Cai Shengqin analyzed Coetzee's novel Disgrace from a perspective of clash of cultures and civilizations, considering clashes between races showed in novel Disgrace was a reflection of clashes in cultures and civilizations and pointing out the practical significance of this theme in Coetzee's novels; "Deconstruction of Binary Opposition and Decline of Colonialism" (Wan, 2005) by Wan Mei considered novel Disgrace reflected the decline of colonialism in South Africa day by day and through the overturn and deconstruction of the former social form of binary opposition in South Africa in the novel to criticize euro centrism. "Domain of Otherness: Hope of Reconciliation-Interpretation of Post-colonialism in Disgrace (Yan \& Dong, 2006) by Yan Xiaochuan and Dong Gefei started with the opposition and clash between two races, black and white in the history of South Africa and pointed out Lucy's behavior showed hope of reconciliation of races which surpassed races, cultures, 
history and sex; "On Discourse Feature of Post-colonialism in Coetzee's novel Disgrace" (Wei, 2006) by Wei Ling considered the novel Disgrace revealed trauma brought by colonialism to South Africa and the novel Disgrace also reflected the hope for South African society to go to harmony after a racial segregation time.

And there were also papers with criticism on Coetzee's novels from a perspective of religion. For example, "On Religious Unconsciousness in Waiting for the Barbarians" (Chen, 2004) considered that Coetzee's novel, Waiting for the Barbarians was permeated with religious unconsciousness to be an allegory about humanity. This paper attempted to find out influences on the theme and narrative form of the novel, Waiting for the Barbarians by the religious consciousness in Bible.

Papers proceeding discussions from a perspective of individual survival such as "Individual's Disgrace and Hope-J.M. Coetzee and His Work Disgrace" (Luo, 2005), pointed out the individual's disgrace showed in Disgrace was caused by history and the hope of remedy lay in bearing the current disgrace and facing the future. "On the Existential Plight as Expressed in Coetzee's Disgrace" (Cai \& Tuo, 2006) considered that Disgrace reflected the writer Coetzee's humanism care and this work showed emotional indifference between people in life and a worrying living condition in modern society. "On J.M. Coetzee's Life \& Times of Michael K" (Zhai \& Liu, 2006) by Zhai Yejun and Liu Yongchang thought that Coetzee's novel Life \& Times of Michael K reflected human's distressing experience in war times showed a survival predicament experienced by people in an atheistically age and had a strong humanism care.

There were few papers discussing the artistic technique and artistic characteristics in Coetzee's novels. Among them, "Building a Myth in Post-colonialism Literature-J.M. Coetzee's Art of Novel" (Ren, 2003) by Ren Yiming discussed the artistic characteristics in Coetzee's novel writing as a whole and considered Coetzee's novels were "good at application of metaphor" by interspersing recreated myth into novels to produce rich images and had a very unique artistic style. "Foe: A Deconstructive Pastiche of Defoe's Novels" (Duan \& Lu, 2004) by Duan Feng and $\mathrm{Lu} \mathrm{Li}$ 'an expounded and proved the rewriting technique of pastiche from Robinson Crusoe in Coetzee's novel Foe and considered Coetzee queried the reliability of reality in novels through this technique and conveyed his reflection on history, language and narration through his works.

Through analyzing papers studying Coetzee's novels above, we can find the following characteristics:

Firstly, as for the concern extent for studies on Coetzee's different novels, most attention was paid to Disgrace. There were more analyses and reviews on his single novel Disgrace than that on other novels by him. Coetzee's representative work is Disgrace, which was firstly translated into Chinese, therefore this novels got more attention from Chinese people naturally so there were more reviews on it.

Secondly, analyses on Coetzee's novels by Chinese readers won't break away from reviews and analyses on race relations and post-colonialism in his novels. Significance of post-colonialism in Coetzee's novel writing was expounded at great length; however, there were few discussions on form of creation and writing style in Coetzee's novel writing.

Moreover, so far, there were no unified translated names in Chinese for some of Coetzee's novels and there were some mistranslations due to introducing Coetzee and his works in a hurry.

\subsection{Reception of Readers for Coetzee's Novels in Mainland China}

Coetzee's winning of Noble Prize also served as a boundary for the reception of readers for Coetzee's novels in China. Before that, only Disgrace among Coetzee's novels was translated into Chinese in mainland China with a flat sales volume. However, after this period, the sales volume of his novels increased greatly mainly due to his wining of Nobel Prize in Literature. After Coetzee won the prize, as time went on, the sales volume of his novels dropped again. Compared to fantasy novels and traversing novels which are popular among teenagers, the sales volume of Coetzee's novels as serious literature is not high in China. And this phenomenon above was mainly caused by the following reasons:

Firstly, drive by economic profit. Booksellers didn't publish Coetzee's novels in quantity before he was awarded Nobel Prize, however, several months later after he won the prize, most of his novels were translated into Chinese and published quickly. They seized the opportunity of Nobel Prize to carry out propaganda and book marketing. Therefore, it caused this phenomenon that after a significant increase in the sales volume of books and publishers competing to publish his books after Nobel Prize was awarded then gradually faded after the craze.

Secondly, the reception of Coetzee's novels was different among common readers and professional critics in China. Professional critics paid attention to the critical consciousness in Coetzee's novels, while most common readers read Coetzee's works as an entertainment. Professional critics didn't provide guidance to common 
readers who read Coetzee's novels, thus resulted in disjunction between critics and common readers. That's why as time went on his novels were forgotten by people.

Translation is also a reason for why Coetzee's novels were not popular in China. Translation cannot completely express the style and cultural meaning of languages and Chinese readers cannot obtain complete meanings of Coetzee's novels through reading, just like being separated by a window paper. That's also a reason for why Coetzee's novels were not popular in China.

Certainly, the first and foremost reason for why Coetzee's novels were not popular in China is differences in cultural and historical background. That's because there is neither drastic racial conflict in China as that in South Africa nor such a long history of colonization. Therefore, the world reproduced in Coetzee's novels was completely strange to Chinese readers. That's why Coetzee's works cannot raise concern from common readers.

\subsection{Consumption of Serious Literature in an Age of Mass Culture}

The consumption condition of Coetzee's works in China reflected the consumption of serious literature in China from another perspective. The literature consumption in current China is getting "middle-class-oriented, younger-age-oriented, idolized, audio visual, visualization, entertainment and recreation oriented" (Ma, 2008). There's no market for elegant and serious literature. Therefore, there were fewer and fewer contemporary Chinese writers who have writing styles with criticism and disapproval but amusement-oriented creation method instead.

The reason for this phenomenon is related to the rising of mass culture. Mass culture developed under the common effect of commodity economy and modern media as an inevitable result in the development of modern history. Culture consumption in film and television and web fiction gradually became a mainstream consumption mode and traditional serious literature gradually lost its market in the mass and became some intelligentsia's choice.

If not accepted by the mass, a literature work is very difficult to survive and to be passed down. That's how serious literature fell into a plight. In history, not a few literature works were passed down and became classics just because they were easily accepted by common people, while those literature works exclusively read by a certain class just had a mediocre influence due to a lack of readers. For example, Classics of Poetry in ancient China included literature works in three kinds "Feng", "Ya" and "Song", in which "Feng" were songs created by common people, which were popular but not appeal to refined taste. Writers and readers of "Ya" and "Song" were mainly noble and intellectual. However, the most widely spread in later generations was "Feng", just because it's popular and understandable with a solid mass base.

\section{Conclusion}

Serious literature, especially Nobel Prize winning works are in a plight in current society. Its influence declines with its readers decreasing. Attention must be paid to literature consumption in mass culture because only those works with a large readership could have a longer vitality.

And literature researchers and common readers also "each care their own business". Researchers' various analyses on Coetzee's novels cannot raise common people's interest or produce any instructive effect. Intelligentsia and the mass are disjointed. All these can result in a decline of serious literature in current society.

\section{References}

Attridge, D. (1998). In J. M. Coetzee, \& S. Kossew (Eds.), Literary Form and the Demand of Politics: Otherness in J.M. Coetzee's Age of Iron (pp. 198-213). New York: G. K. Hall.

Cai, S. (2004). Echo of Realism Literature towards Clash of Civilizations Theory-Perusal of Coetzee's Novel Disgrace. Foreign Literature Study, (4), 97-101.

Cai, T., \& Yan, X. (2005). Historical Memory and National Allegory-on Disgrace, (6), 33-37.

Cai, Y., \& Tuo, J. (2006). On the Existential Plight as Expressed in Coetzee's Disgrace. Journal of Lanzhou University, (1), 106-111.

Chen, X. (2004). On Religious Unconsciousness in Waiting for the Barbarians. Journal of Zhaowuda Mongolian Teachers College, (6), 57-58.

Duan, F., \& Lu, L. (2004). Foe: A Deconstructive Pastiche of Defoe's Novels. Contemporary Foreign Literature, (4), 48-54.

Li, Y. (1991). African Literature in the 20th Century (pp. 228-229). Beijing: Beijing Language and Culture University Press. 
Luo, J. (2005). Individual's Disgrace and Hope-J.M. Coetzee and His Work Disgrace. New Forum of Chengdu, (S1), 178-179.

Ma, D. (2008). Four Characteristics of the Current Fashion-oriented Literature Consumption. Academic Journal of Jianyang, (6), 97-100.

Ren, Y. (2003). Building a Myth in Post-colonialism Literature-J.M. Coetzee's Art of Novel. Social Watch, (4), 30-31.

Shi, S. (2004). Unordered Revelry and Circular Shame-Coetzee and his Disgrace. Journal of LaiYang Agricultural University, (2), 51-54.

Wan, M. (2005). Deconstruction of Binary Opposition and Decline of Colonialism. Journal of Nanjing University of Aeronautics \& Astronautics, (1), 68-71.

Wang, L. (2000). An Elegy to Colonialism-Criticism on Booker Prize Winning Novel Disgrace. Contemporary Foreign Literature, (3), 162-165.

Wei, L. (2006). On Discourse Feature of Post-colonialism in Coetzee's novel Disgrace, (2), 29-33.

Yan, X., \& Dong, G. (2006). Domain of Otherness: Hope of Reconciliation-Interpretation of Post-colonialism in Disgrace. Journal of Northeastern University, (1), 72-78.

Zhai, Y., \& Liu, Y. (2006). On J.M. Coetzee's Life \& Times of Michael K. Foreign Literature, (2), 70-72.

Zhang, C., \& Guo, Z. (2001). Costs for Cross the Border-Interpreting Coetzee's Booker Prize Winning Novel Disgrace. Foreign Literature, (5), 86-89.

Zou, H. (2004). Waiting for the Barbarians-Postscript of Translation (p. 222). Hangzhou: Zhejiang Literature and Arts Press.

\section{Copyrights}

Copyright for this article is retained by the author(s), with first publication rights granted to the journal.

This is an open-access article distributed under the terms and conditions of the Creative Commons Attribution license (http://creativecommons.org/licenses/by/3.0/). 